\title{
Faglig diskussion: Filmvidenskab - et spørgsmål om biologi eller kultur
}

\author{
Redigeret af Nete Nørgaard Kristensen (anmelderredaktør) i samarbejde med \\ Mediekulturs øvrige redaktion.
}

I MedieKultur nr. 38 anmeldte Søren Kjørup Torben Grodals bog Filmoplevelse - en indforing $i$ audiovisuel teori og analyse. Her følger en redigeret version af dels Torben Grodals svar på anmeldelsen og Søren Kjørups replik.

\section{Debatindlæg af Torben Grodal}

Kjørups anmeldelse af Filmoplevelse i MedieKultur nr. 38 bærer præg af, at hans opfattelse af filmteori blev dannet for 35 år siden, hvor humanistisk forskning isolerede sig fra naturvidenskaberne. I indledningen til anmeldelsen signalerer Kjørup, at han synes, at det er fjollet at inddrage evolutionær og psykologisk viden til forståelse af film. Tilsyneladende ønsker han sig en lærebog, som man skrev den i 70erne, hvor sprog var grundlaget for at analysere billeder. Som semiolog gik Kjørup endda længere end de fleste andre af slagsen, idet han satte sig for at vise, at lighed mellem billede og det afbildede var konventionel som i talesproget. Han undgik derimod de dele af strukturalismen, der skulle vise sig brugbare i filmanalysen: udsigelsesanalysen og narratologien. I sin anmeldelse af Filmoplevelse omtaler Kjørup i øvrigt ikke de kapitler, der omhandler fortælleteori og udsigelsesanalyse. At film fortæller historier har Kjørup stadig til gode at forholde sig til.

Kjørup bebrejder mig, at jeg interesserer mig for, "hvad der gør [film]mediet forståeligt og spændende (...) ikke filmen som 'sprog"” og giver således selv en nøgle til at forstå, hvorfor filmsemiotikken i mange henseender var en blindgyde. Den talte om fonemer, ikke om filmoplevelse og følelser. Men film er et medie, ikke et sprog, og dens virkemidler forstås bedst i sammenhæng med psykologi. Receptionsstudier har modbevist, at man skal lære at se film på samme måde, som man lærer et sprog. Brugen af sprogvidenskabelige termer har da heller ingen forklaringsværdi, og semiotiske filmanalyser er i realiteten indholdsanalyser, der blot benytter ord som 'tegn' som en videnskabelig udsmykning. Filmsemiotik er bundet til en statisk og ukropslig teori, der ikke begriber de levende billeders æstetik, fx den stadige emotionelle pulsering og sammenkobling af aktørernes handlingspotentiale med den visuelle oplevelse.

Kjørup hævder, at jeg i min omtale af tidligere filmteori nok så ofte gør det for "at fortælle at tidligere filmteori tog gruelig fejl". Hovedparten af den tidligere filmteori fremstiller jeg faktisk som fornuftig. Det er kun psyko-semiotikken, som jeg finder uanvendelig. Det er i lyset af semiotikkens konsekvente negligering af psykologi, at Kjørup fremsætter, hvad han kalder sin væsentligste faglige indvending mod min bog, nemlig at jeg her fletter perceptionen af filmens todimensionale lærred sammen med sansningen af virkelighedens tredimensionale rum. Kjørup mener, at mens øjet i den ene situation ser billeder, ser det i den anden situation 'virkeligheden'. Film er altså i følge Kjørup flade tegn på et lærred. Dette er dog ingenlunde tilfældet: Film er en generator af visuelt input, lys, 
der oftest har lighed med, hvad nogle fænomener og rum ville udsende $\mathrm{i}$ den virkelige verden. Lysdata kan være computergenererede eller fotograferede. Hvis lyset har data, der muliggør, at øje og hjerne laver tredimensionelle oplevelser, er det for så vidt ligegyldigt, om lyset kommer direkte fra verden eller fra en skærm eller et lærred. De dybdevirkninger, der kommer af at have to øjne, er kun af betydning for 3D-virkning på helt nære afstande. Den altafgørende oplevelse af 3D kommer fra teksturgradienter, skygger, overlapning, synspunktbevægelse osv.

Semiotikeren forstår ikke de audiovisuelle mediers virkning, fordi han tror, at billedet er et skrifttegn: Først ser vi udtrykket hest, og så aktiverer vi forestillingen om en referent. Nej, i biografen vælter der lys ind i øjet, og hjernens syns-analysatorer registrerer hesteoplevelser. De overordnede centre i hjernen vil bemærke, at det drejer sig om en film, og det trækker som regel lidt fra virkelighedsoplevelsen. Kjørup siger: "Det for mig grundlæggende spørgsmål om, hvorfor billedet på lærredet opleves som så virkeligt, finder Grodal det tilsyneladende overflødigt at stille.” Jeg stiller faktisk dette spørgsmål, men løser det ved radikalt at omformulere problemet på to ledder: Først ved at beskrive, hvorledes oplevelsen dannes ved tusindvis af processer $\mathrm{i}$ centre i hjernen. Når der kommer lys ind i hjernen, vil nogle af disse centre råbe: "match, en hest", andre vil aktivere emotioner, mens atter andre udtrykker forbehold: "jamen, det drejer sig om en film". Problemet består ikke i at beskrive, hvorfor visuelle simuleringer opleves som virkelige, men i at beskrive de processer der afsvækker oplevelsen. Dernæst ved at generalisere beskrivelsen af fænomeners virkelighedsstatus. Virkelighed er noget, der forekommer i alle grader og afskygninger, og en filmsekvens' virkelighedsstatus evalueres af hjernen med hensyn til tusindvis af parametre. Øjenfarve $\mathrm{og}$ ansigtsform på Marlon Brando er som et Baziniansk virkelighedsaftryk til stede i vores hjerner, men hans hensigter er spillede, og vi kan ikke røre ham, for taktilitet overføres ikke af film.

Dele af humaniora har i årtier indædt modsat sig naturvidenskabens 'affortrylning' (Weber) af virkeligheden. Diltheys Geistesgeschichte og Frankfurterskolems kritiske teori og positivismekritik er blot eksempler på en sådan modstand, og så vidt jeg kan se, placerer Kjørup sig i en tilsvarende position. Det fremgår bl.a. af hans bog Humanvidenskaberne, hvori han benytter en dobbelt strategi for at restaurere humaniora. Fortielsesmetoden går hånd i hånd med skepticismen i forhold til den naturvidenskabelige tænknings gyldighed. De kvantespring i forståelsen af, hvorledes krop og bevidsthed hænger sammen, der har præget særligt anden halvdel af det 20. århundrede, omtales ganske enkelt ikke. Computervidenskab, neurologi, kognitionsvidenskab, biologi og evolutionsvidenskab har gjort det 19. århundredes idealistiske skelnen mellem ånd og legeme, humaniora og naturvidenskab, meningsløs. Kjørup støtter sig i bogen til retorik, semiotik, hermeneutik, strukturalisme, marxisme og dekonstruktion, men værdiger ikke det nye tværvidenskabelige paradigme en linje. Diltheys åndsvidenskab opstod bl.a. som en reaktion på opstarten af den moderne psykologi, $o g$ Kjørups opfattelse af humaniora udelukker psykologi, således at sprog og tegn eksisterer i en kropsløs ånd.

1970ernes videnskabskritik er en vigtig forudsætning for at forstå, hvorfor semiotik og kritisk videnskab udartede sig til dekonstruktionens irrationalisme. Kjørup befinder sig ganske vist ikke godt i det selskab, men hans egen relativisme, skepticisme og videnskabskritik, som han kalder situationisme, gør ham forsvarsløs. Nok kritiserer han de postmodernistiske irrationalister, men de er, modsat naturvidenskab og psykologi, samtalepartnere. Filmoplevelses inddragning af mainstreampsykologi ses derfor af Kjørup som et idiosynkratisk særstandpunkt. Men moderne medievidenskab bør ikke snævert støtte sig til gammelhumanismens kamp mod den videnskabens 'affortryllede' verden, men orientere sig frit på tværs af det forældede skel mellem humaniora og naturvidenskab.

I Filmoplevelse er dette udgangspunktet, og bogen er en 'state of the art'-fremstilling af fortælleteori, æstetisk effekt, skuespil og rolle, filmens emotioner, film og samfund, og meget mere. Den fremstiller efter min mening de langtidsholdbare og anvendelige dele af den filmvidenskabelige tradition i de sidste 90 år, inklusive de psykologiske og fænomenologiske dimensioner, som kritisk videnskab og semiologi forsøgte at fortrænge. Derfor ser bogen noget anderledes ud end 70ernes film-som-sprog bøger.

Torben Grodal Professor Afdeling for Film- \& Medievidenskab Kobenhavns Universitet 
Soren Kyorups respons til Torben Grodal

\section{Debatindlæg af Søren Kjørup}

Torben Grodal mener, at min anmeldelse af hans seneste bog "bærer præg af, at [min] opfattelse af filmteori blev dannet for 35 år siden, hvor humanistisk forskning isolerede sig fra naturvidenskaberne. "Nu har jeg lige genlæst anmeldelsen (hvad jeg også vil anbefale læserne af denne lille diskussion at gøre!), og selv synes jeg, at den snarere bærer præg af, at jeg irriteres over dårligt gennemarbejdede og sjusket redigerede bøger - og specielt når det gælder indføringsbøger.

En af mine indvendinger mod Grodals "indføring i audiovisuel teori og analyse" er, at han ikke har givet sig tid til at genopfriske flere af de ældre teorier, han skriver om. Noget tilsvarende kan siges i forbindelse med hans omtale af nogle af mine tidligere skriverier. Havde han lige kigget en ekstra gang, havde han nemlig ikke blot fået titlen på min bog Menneskevidenskaberne rigtig (og opdaget at jeg ikke blot redegør for og diskuterer de seks videnskabelige traditioner han fejlagtigt mener, jeg "støtter" mig til, men faktisk også en syvende, nemlig positivismen). Han var også blevet mindet om, at jeg aldrig har skrevet et pænt ord om psyko-semiotikken, og at jeg gang på gang har gjort det klart, at jeg stort set deler hans opfattelse at "semiotiske filmanalyser er i realiteten indholdsanalyser, der blot benytter ord som 'tegn' som en videnskabelig udsmykning".

En enkelt bemærkning i Grodals modanmeldelse af mine skrifter giver mig imidlertid mistanke om, at problemet ikke er så enkelt som at han ikke ikke har nået at genlæse dem; måske har han overhovedet aldrig har læst dem. Den bemærkning, jeg tænker på, er denne om "semiotikeren", der vist skal være mig: "han tror, at billedet er et skrifttegn: Først ser vi udtrykket hest, og så aktiverer vi forestillingen om en referent." Selv blandt semiotikere skal man vist lede længe for at finde nogen, der er i stand til at rode så meget forskelligartet sammen i én forvrøvlet formulering. Skulle jeg forsøge at reformulere dette, som jeg faktisk selv tænker det, ville det blive noget i denne retning: "At se at et billede forestiller en hest, er at se flader, former og farver som en konfiguation der passer med ens heste-skema." Og som en lille ekstra forklaring kunne jeg tilføje: "De mentale mekanismer, vi benytter til at identificere en bestemt datamasse kaldes ofte skemaer (eller skemata)."

Tilføjelsen er imidlertid ikke min egen formulering, men et citat fra side 18 i Grodals bog (med kursivering og kommafejl og det hele). Den meget opmærksomme læser vil dog nok ane, at selv om vore synspunkter her praktisk talt falder sammen, så er der alligevel nuancer i formuleringerne som peger i forskellige retninger. Det springende punkt vil være Grodals brug af ordet "datamasse", et ord som ligger mig ret fjernt i forbindelse med filmoplevelse. Og jeg står helt af hvis det (som det fremgår af Grodals indlæg) ikke længere skal være tilladt at sige, at i biografen ser vi levende billeder, fordi vi reduktionistisk skal holde os til at sige, at vi făr "visuelt input".

Netop! vil Grodal her udbryde: Der kan I selv se at ham Kjørup er sådan en gammelhumanist, der ser naturvidenskabens erkendelser og vokabular som en besmittelse af det ægte og rene humaniora!

Selv har jeg nu snarere en fornemmelse af, at Grodals analyser af filmoplevelsen oftest har karakter af (helt udmærkede) fænomenologiske skildringer, der blot benytter ord som "datamasse" som en (natur)videnskabelig udsmykning (for nu at parafrasere ham selv). Undertiden endog med komiske resultater: "... når der kommer lys ind $\mathrm{i}$ hjernen"!

Jeg er enig med Grodal i, at det er en diskussion værd om vi repræsenterer to forskellige paradigmer i filmvidenskaben (selvom jeg altså ikke helt kan identificere mig med det parodiske paradigme, han vil putte mig ind i). Men der er flere passager i hans bog end den om skemaer, der får mig til at overveje om forskellen mellem vore holdninger ikke er en del mere banal end som så. Side 27 sætter han således naturalistiske og konstruktivistiske forklaringer over for hinanden, altså forklaringer der "bottom up" tager udgangspunkt i biologi og den slags, og forklaringer der "top down" snarere tager udgangspunkt i noget kulturelt (og jeg vil altså meget hellere opfattes som konstruktivist end som semiotiker). Og så skriver han minsandten:

"Forskellen mellem de to teorityper er imidlertid mere et spørgsmål om omfang, dvs. hvor om [sic] meget man kan forklare hhv. konstruktivistisk eller [sic] naturalistisk. En naturalistisk forklaring kan aldrig forklare alle betydningsprocesser: Nogle må nødvendigvis forudsætte viden erhvervet via den personlige og sociale udvikling (socialiserin- 
gen). Konstruktivistiske forklaringer kan heller ikke forklare alt: De må nødvendigvis forudsætte at øje og hjerne har visse medfødte træk, der f.eks. gør de muligt at skelne lys, farver osv."

Jeg er rørende enig - bortset fra at jeg nok ville sige, at ingen betydningsprocesser kan forklares naturalistisk, i hvert fald sådan som jeg bruger ordet "betydning". Men jeg er rørende enig i, at vi konstruktivister naturligvis ikke kommer uden om at det at mennesker kan skelne farver, er et sikkert tegn på at den menneskelige hjerne rummer mekanismer der gør det muligt at skelne farver. Spørgsmålet er bare om dette må medføre, at hjerneforskning er en gren inden for filmvidenskaben.

Grodal synes det er spændende og interessant at få forankret filmoplevelsen i biologi, og at det er kildrende at flirte med naturvidenskabelig og psykologisk jargon og helst på engelsk. Jeg synes det er mere spændende og interessant at lede efter mønstre i den brug og forståelse af de levende billeder, som har udviklet sig kulturelt gennem filmens 110 år, og at fremstille resultaterne i en terminologi, der ligger så tæt på dagligdagens danske som muligt.

Soren Kjorup

Professor

Institut for Kommunikation, Fournalistik og Datalogi

Roskilde Universitetscenter 